\title{
THE STUDENTS' LEARNING STRATEGY AND MOTIVATION IN DEVELOPING THEIR SPEAKING ABILITY AT SIXTH SEMESTER OF ENGLISH DEPARTMENT (IAIN PAREPARE)
}

\author{
Era Dahlan ${ }^{1}$, Abd. Haris Sunubi ${ }^{2}$, Ahdar $^{3}$ \\ English Program, Tarbiyah Faculty, State Islamic Institute Parepare ${ }^{123}$
}

\begin{abstract}
The aim of this research was to know the Students learning startegy and motivation in developing the students' speaking ability at sixth semester of English department (IAIN Parepare). The researcher was applying at sixth semester of English department (IAIN Parepare) through a descriptive qualitative research. This research were using three kinds of instruments. The first instrument was test, where the purpose of this instrument was to know the student ability in speaking. The second was interview, the aim of this instrument was to know what strategy that the student use to develop their speaking. The last was questionnaire, where this instrument was to know the motivation of the student in order to develop their speaking. After analyzing the data from the questionnaire the researcher found that students in the high and low category have the same strong motivation in developing their speaking. However, in terms of using strategy, the students in high category use more variated strategies than the low category. The students in high category mostly apply cognitive and metacognitive strategy while the students in low cataegory mostly used social strategy.
\end{abstract}

Keywords: Speaking, Learning Strategy, and Motivation.

\section{Introduction}

In Indonesia, English becomes an important language besides Bahasa Indonesia, especially in the education aspect. Based on the importance of English, students are required to master four English skill. Among the four key language skills, speaking is deemed to be the most important skill that must be mastered well in learning a new language. However, speaking a foreign language is not an easy skill to be 
mastered by students. Students consider speaking as the most difficult skill since it needs great courage as well as preparation to speak well in the new language.

For most people, learning to speak became the most difficulty when they learn a foreign language. They have to learn about grammatical, pronunciation, and vocabulary at the same time. In receiving the lesson, especially English, the students face some difficulties. The difficulties faced by students are not the same. Every learner has a different ability to catch the material. They have their own ways to be able to understand the lesson.

On the other hand, the other students cannot understand the lesson without the teacher explained in detail. Therefore, the students have a different strategy in studying. Theoretically, the way of learning is called a learning strategy. In fact, in the teaching- learning process, sometimes the teachers do not apply an appropriate learning strategy for teaching speaking. Therefore, the students itself has to have their own strategies to help them in studying. Several problems which are faced by poor students in learning English as a foreign language. First, students cannot sustain spoken interaction beyond short segments. Second, students experience frequent communication breakdowns and misunderstandings. Third, students lack vocabulary that is needed to talk about common utterances. The last, their spoken English does not sound natural. In order to become successful in speaking, students need particular learning strategies. Some students are good and some of them are failed. It might be caused by language learning strategies.

From the statement above the researcher conclude that learning strategies can be used to solve students' problem in speaking. Other than that in the process of learning, motivation can be said as an inner drive to achieve learning activity so the purpose of the subject learning can be maintained in an educational environment; motivation is one of the very important factors to encourage a learner to learn more rapidly and effectively.

The motivation may come from the students themselves that are the intrinsic, 
or outside of the students, that is, the extrinsic, for those who have intrinsic motivation, they will have strong responsibility to learn. According to Sardiman motivation can be defined as the overall driving force in the student who raises, ensuring continuity and provide direction and learning activities, so that the objective can be achieved. It means that, motivation is a force to encourage or provide direction to students so that students can easily achieve the goals of their learning.

According to Nicholson there are some characteristics of student motivation, they are interest in learning, participation, focus of the work activities in classroom, and enthusiasm doing task. It means that, the students who have high motivation, they will always enjoy in learning when the teachers give task, they will enthusiasm and focus to do task.

From all of the statement above researcher can concluded that learning strategies is important for students to improve their speaking. They can speak English very well when they have good speaking strategies. On the other hand, they cannot speak English well if they do not have good speaking strategies and students can improve their speaking if they have high motivation and good independent learning. On the other hand, they cannot improve their speaking when they do not have high motivation and good independent learning.

Based on the researcher observation before toward student English department of IAIN Parepare, it is found that some students were willing to speak English voluntarily. Those who were willing to speak English voluntarily seemed to be better speakers of English. It is also found some students were unwilling to speak English, they would speak up when they asked to.

Based on the researcher interview with some students, it is found that there were some factors that make the students failure in learning speaking. First, they were very of making mistakes. It could be one of the effects of their previous learning experience. Second, they were afraid of failure, laughter, and ridicule. 
Third, the students were seldom to speak English because of the lack of vocabulary.

Considering the result of the researchers' observation and interview with some students, so the researcher would like to look further and conduct research about the students learning strategy and motivation to developing their speaking ability at sixth semester of English department (IAIN parepare).

According to Bailey in Kaharuddin, speaking is the production skill that consists of producing systematic verbal utterances to convey meaning. Brown, Burns \& Joyce are of the opinion that speaking is an interactive process of constructing meaning that involves producing, receiving and processing information. In addition, Bahar defines speaking as to say something from feeling and mind expressed through the sequence of sound (pronunciation), vocabulary, phrases, and sentences (grammar) that contain meaning (pragmatic) and (Semantic) to convey a particular function within a language.

There are many definitions of speaking in language learning proposed by some experts. Clark and Clark define that communication deals with two basic activities: listening and speaking. In speaking, people express their thoughts through words and talk about perceptions, feelings and intentions they want other people to grasp and understand. Meanwhile, Spratt points out that using speech to convey meaning to others is involved in speaking. While Brown and Yule in Nunan suggest that spoken language consists of short and often incomplete utterances in a level of pronunciation. Repetitions, the use of fillers such as 'well', 'oh-uh' and 'oh' and overlap between one speaker and another can be often found in speaking.

Learning strategy is step taken by people to achieve the goals of learning. Learning strategies are defined as steps taken by students to enhance their own learning. The strategies can be done inside or outside of the classroom based on the students themselves. A learning strategy here refers to a choice that the learner makes while learning or affects learning to process. There are many definitions of learning strategy described by expert. Weinstein and Mayer define learning strategies as "behaviors and thoughts in which a learner engages and which are intended to 
influence the students encoding process".

\section{Cognitive strategies}

They are used to manage directly incoming information, and use it skillfully in order to improve learning. They are more limited to specific learning tasks; they cannot be used for all the language tasks. They involve strategies like translation, note-taking, deduction, and contextualization.

\section{Meta-cognitive strategies}

Involve thinking about the learning process, planning for learning, monitoring of comprehension or production while it is taking place, and self-evaluation after the learning activity has been completed". Meta- cognition is simply thinking about your process of learning and seeing if it is going in the right way, and reflecting on the effectiveness of the strategies used so far.

\section{Social-affective strategies}

Represent a wide grouping that involves either interaction with another person or conceptual control over affect. This means that the learner either interacts with others in order to support and promote learning, as in cooperation or asking questions for clarification, or uses some kind of control over his/her emotions including anxiety and stress to assist learning.

Oxford classifies Language Learning strategies into direct and indirect strategies. The category of direct strategies consists of memory strategies, cognitive strategies and compensation strategies while indirect strategies comprise metacognitive strategies, affective strategies and social strategies.

The direct strategies are beneficial to the students because they help store and recover information. These strategies help students to produce language even when there is gap in knowledge. They also help to understand and use the new language. The Direct Strategies are formulated as follows:

Memory strategies involve the mental process for storing new information in the memory and for retrieving them when needed. These strategies have four 
categories (Employing Action means using Physical Response or sensation using mechanical technique, Review well means structured review, applying images and sounds means using imagery, mapping using keyword, representing sound in student memory, Creating student mental means grouping, associating/elaborating or debating)

Cognitive strategies are a conscious way in processing the target language. It involves four categories as:

Indirect strategies work together with the direct strategies. They help learner regulate the learning process. These strategies support and manage language learning without direct engagement and therefore called indirect strategies. The Indirect Strategies are formulated as follows:

Meta-cognitive strategies (they allow students to control their own cognition, which means to make arrangements upon the learning process by using functions such as centering, arranging, planning and evaluating.)

Affective strategies they help to regulate emotions, motivations and attitudes. (they include lowering anxiety, encouraging oneself and taking one "emotional" temperature.)

Social strategies (they help students learn through interaction with others. They include asking questions, cooperating with others and empathizing with others.) that individuals use to help them comprehend, learn, or retain new information.

However, oxford also points out learning strategies are specific actions taken by students to help their own learning, to make the learning easier, faster, more enjoyable, more self-directed, more effective and more transferable.

Motivation is an intrinsic phenomenon that is affected by four factors: Situation, Temperament, Goal and Tool. However, tools to reach the target. People are motivated for achieving to the goals, necessities and instincts. Academic achievement has a special importance for seekers of science and students.

According to Dornyei and Otto, motivation can be defined as the dynamically 
changing cumulative arousal in a person that initiates, directs, coordinates, amplifies, terminates, and evaluates the cognitive and motor process whereby initial wishes and desires are selected, prioritized, operational zed, and (successfully or unsuccessfully) acted out. Motivation directs behavior and also initiates it. When we are sleepy we seek rest, not doing something else. When we are motivated by a desire for thrills or excitement, we may well try to do something fun for example fishing, swimming, diving, etc. So, motivation gets us up and doing, it energizes us, and it defines the directions or nature of the resulting behavior.

Motivation divided into two part, they are intrinsic and extrinsic motivation. They are intrinsic motivation and extrinsic motivation. Intrinsic motivation is appeared personal such as their comfort, happiness, interest. if the students have intrinsic motivation, they was easier and more enthusiasm in learning. Students who have intrinsic motivation also will be quicker and more simply to achieve their goals. Extrinsic motivation is motivation which come from not from inside of ourselves but from outside, it means that extrinsic motivation is motivation that caused by outside factors of situation.

According to Schunk Intrinsic motivation refers to motivation concerned in activities for its own sake. Internal motivation involves motivation to do something for its own desire. This motivation is appeared from ourselves. The students who have intrinsic motivation will study hard and enjoy the teaching and learning. Oemar Hamalik explains that extrinsic motivation is motivation that caused by outside factors of situation. According to Marsh extrinsic motivation is "Experienced by students when they receive a reward, or avoid punishment, or in some other way unconnected with the task earn approval for particular behavior.

\section{Research Method}

In this study the researcher will use qualitative descriptive method. The focus of this study is to know the students' learning strategy and motivation in develop their speaking whereabouts the researcher analyzed learning strategy of students in two 
facets that according to Oxford, they are direct strategy and indirect strategy. Also the researcher analyzed motivation of the students in two facets, they are intrinsic motivation and extrinsic motivation Then, after the researcher get the data about students' learning strategy and motivation, for more the researcher was identify the students' skills in speaking.

Researcher has conducted the research in English Department at the students that have learned about speaking. The researcher used technique simple random sampling in this research because technic simple random sampling is technique for getting samples that are directly carried out on the sampling unit, and then each sampling has the same opportunity to represent the population. The samples of the research were around twenty-fives students of English Department. In this research, the researcher uses interview, questionnaire and test.

\section{Findings and Discussion}

The finding shows that from 25 samples there were 7 students' in the low category and 18 students in the high category. Students who fall into the category of low speaking, most of them were still lacking in pronunciation and accuracy. For more details, the researcher has classified them as approximately (40\%) of the total respondents, namely 10 students' who answered questions and fulfill classification of excellent score. There were around (32\%) of the total respondents, 8 students' who answered questions and fulfill classification good. There were around (28\%) of the total respondents, namely 7 students' who answer questions included in fair classification. And none of the students were included $(0 \%)$ in the classification of poor and very poor.

Learning strategies are specific action taken by students to help their own learning, to make the learning easier, faster, and more enjoyable. This part contains the students' learning strategies analyzed in relation with Oxford's theory about learning strategies; they are direct strategies (memory, cognitive) and indirect strategies (metacognitive, affective, social). After interviewed in both groups students 
who have learned speaking with question designed to know their learning strategies. The researcher noted that most often learning strategies employed by high speaking performance students were (1) listening to English songs/audio (cognitive), (2) watching English movies (cognitive), (3) reading English books/novels (cognitive/metacognitive), (4) reciting song lyrics (cognitive/ metacognitive), (5) analyzing English articles, (6) reviewing lessons (cognitive), (7) practicing with friends (social/metacognitive), (8) talking to themselves in English (metacognitive) (9) using synonyms in English (cognitive), and (10) repeating words or sentences with their conversation partners to achieve better understanding (cognitive).

In addition, they were more aware and more creative in using these strategies which made them more successful in completing language tasks. On the other hand, the strategies that were frequently used by low speaking performance students were: (1) looking up the dictionary (memory), (2) asking friends (social), (3) practicing pronunciation (cognitive), and (4) memorizing sentences (memory). The result of the interview, the researcher noted that the learning strategies most often used by the students with low speaking performance were usually memory and social strategies. Meanwhile, cognitive, metacognitive, and affective strategies were not so often used.

On the other hand, students with high speaking performance had a better balance in the learning strategies they used. That is, these students' employed memory, cognitive, with much the same degree of frequency. As shown in Table 4.2 all kinds of strategies were usually employed by the high speaking performance students' in learning and practicing speaking. This means that successful language learners demonstrated greater consistency in applying more effective strategies. The findings of the present study are in line with Gharbavi and Mousavi which showed that the higher the level that learners are at, the greater the number of strategies they will apply. Oxford also claims that all language learners ${ }^{e e}$ use learning strategies, but more successful learners use them more consciously, more appropriately, more 
purposefully and more frequently. The opinion above is strengthened by the results of the research from the researcher who found that the large variety of learning strategies used will further support the development of the speaking.

From the result of the questionnaire the researcher noted that there were none of the students' included in (weak) and (very weak) motivation, there was none of the students' include in (very strong) motivation, both of the category high and low have a (strong) motivation in developing their speaking ability. Students with high and low category are mostly in intrinsic motivation. Based on the presentation data, most of the students answered strongly agree and agree in the statement from the questionnaire. The intrinsic motivation means that they are motivated in engaging to go through the learning process because they have internal motivation to do something for their own sake.

When conducting the interview about what kind of learning strategies that they use in developing their speaking, the researcher found several things that showed most of the answer indicate that the students were more inclined to intrinsic motivation. Most of the students mentioned learning strategies that come from themselves. In line with that Schunk said that students' who have intrinsic motivation also will be quicker and more simply achieve their goals because they have motivation inside themselves.

Harmer states that intrinsic motivation takes a vital role in the result of students' language learning. But based on the data there were some students who have a strong intrinsic motivation but was not accompanied by a learning ability especially, in this case in developing their speaking ability.

The result showed that both of the groups the students in the high and low categories have strong motivation in developing speaking. But it is opposite from the results of existing data on learning strategy shows that students who are in the high category have more strategies than students who are in the low category, whereas students who have strong motivation to learn also have diverse ways of learning and 
also good learning achievement. Therefore, it should be emphasized that if a student only has motivation without the conscious feeling to do it, motivation here will not have any effect. So that conclusions can be drawn even if both of the group has strong motivation. students who are in the high category do not just have motivation but they have an awareness in realizing things that make them motivated, one of them is using a variety of different strategies to improve their speaking abilities. And it was not found in students who are in the low category.

\section{Conclusion}

High speaking performance students' usually used all five strategy aspects namely memory, cognitive, metacognitive, affective, and social strategies for enhancing their speaking skills more equally. They had more balance in their use of the various strategies. Meanwhile, the low performance students' tended to focus more on employing social strategies than on memory, cognitive, metacognitive, and affective strategies to enhance their speaking skills. Thus, the low performance speaking students' need to focus more on improving other learning speaking strategies and not be too focused on only social strategies.

The result of students' questionnaires of students' motivation in developing their speaking at sixth semester of English department in IAIN Parepare who have learned speaking have been gathered and analyzed by using scale of Liker. Both of the group have a good motivation with a mean score 69.9 and it was categorized strong.

\section{References}

A, Gharbavi. \& Mousavi,S,A. 2012. Do Language Profiency Levels Correspond To Language Learning Strategy? English Language Teaching.

Arikunto, Suharsimi. 1998. Prosedur Penelitian Suatu Pendekatan Praktek. Cet.11; Jakarta: PT. RinekaCipta.

Bahar, Kaharuddin. 2013. The Communicative Competence-Based English Language Teaching. Yogyakarta : TrustMedia. 
2014. Interactional Speaking: A Guide to Enhance Natural Communication Skills in English. Trustmedia Publishing Yogyakarta.

Brown, H. Doughlas. 1994. Teaching by Prinsiple; an Iinteractive Approach to Language Pedagogy. U.S.A: A Paramount Communications Company.

Enzir, 2011. metodologi Penelitian Kualitatif: Analisis Data. Jakarta: PT RajaGrafindo Persada.

E, Weinstein, C, \& E. Mayer, R, The Teaching of Learning Strategies. Innovation Abstract, the national for staff and organization development \& The W.K Kellogg Foundation. Eric.

Gani , Sofyan A. 2015. Student Learning Strategy for Developing Speaking Ability at 8th Grade in SMAN 3 Banda Aceh. Unpublished Skripsi : Universitas Syiah Kuala.

Hamalik, Oemar. 1995. Kurikulum dan Pembelajaran. Jakarta: Bumi

Aksara. Jones, Rhodi. 1989. Speaking and Listening. London: The Bath Press

Kountur, Roni. 2003. Metode Penelitian Untuk Penulisan Skripsi Dan Tesis. Jakarta : PPM.

Mackey, Alison. \& Susan M.Gass. 2005. Second Language Research; Research, Methodology, and Design. London: Lawrence Erlbaum Associetes, Inc Publisher.

Marsh, Colin. 2010. Becaming a Teacher Knowledge, Skill and Issues. New South Wales: Pearson Australia, Fifth Edition.

M, Sardiman, A. 2011 Interaksi Motivasi dan Belajar Mengajar. Jakarta: Raja Grafindo Persada.

O’Malley, J. M. \& Chamot A. U. 1990. Learning Strategies in Second Language Acquisition. NY: Cambridge University Press.

Oxford, Rebecca. L. 1990. Language Learning Startegies : What Every Teacher Should Know. New York : Newburry House.

Ridianto, 2012. The Contribution of Students' Speaking Learning Strategies and Motivation toward Their Speaking Skill at STAIN Batusangkar. Unpublish Skiripsi: STAIN Batusangkar.

Rod, Ellis. 1997. The Study of Second Language Acquisition. Oxford: Oxford 
Volume 2 № 2 September 2019

University press.

Said, Arsy. 2012. The Effectiveness of Make A Match as Teaching Strategy to The Students Speaking Mastery of The Second Year at Mts DDI,Unpublished Skripsi, Parepare : STAIN Parepare.

Sekolah Tinggi Agama Islam Negri (STAIN) parepare. 2013. "Pedoman Penulisan Karya Tulis Ilmiah”. Parepare.

Sugiono, 2017. Metode Penelitian Pendidikan Pendekatan Kuantitatif, Kualitatif, dan $R \& D$.

Schunk, Dale H, Judith. L. meece, Paul. R. Pintrich. 2008. Motivation in Education in Theory, Research, and Aplication.

Silva, Prucesia Kumara. 2013. Improving Student's Speaking Skill Through the Use of Video Clips. Unpublished Thesis State university of Yogyakarta. 